\title{
RESTORATION OF THE KOKAND PAPER MANUFACTURING AS A NATIONAL BRAND: ITS IMPORTANCE IN THE TOURISM INDUSTRY Mansurov M.Sh. Email: Mansurov636@ scientifictext.ru
}

\author{
Mansurov Muzaffarjon Sharifjon o'g'li - Independent Applicant, \\ FERGANA, REPUBLIC OF UZBEKISTAN
}

\begin{abstract}
: nowadays, the manufacturing of touristic production and the transforming of national production into the brand is very important for tourism development. Nowadays, the manufacturing of touristic production and the transforming of national production into the brand is very important for tourism development. In order to develop tourism in the Ferghana Valley, it is planned to use the renovation of the production of Kokand paper, and also to develop tourist routes along the territories where the paper was produced.
\end{abstract}

Keywords: tourism, national brand, Kokand paper, Samarkand paper, a tourist route, world experience.

\section{ВОССТАНОВЛЕНИЕ КОКАНДСКОЙ БУМАГИ КАК НАЦИОНАЛЬНОГО БРЕНДА: ЕЁ ЗНАЧЕНИЕ В ТУРИСТИЧЕСКОЙ ПРОМЫШЛЕННОСТИ Мансуров М.Ш.}

Мансуров Музаффаржон Шарифжон угли - независимьй заявитель, 2. Фергана, Республика Узбекистан

\begin{abstract}
Аннотация: в статье говорится о развитии туристической индустрии, важнейтем значении производства, продвижения и повышения в ней туристической промышленности и национальной продукиии на уровень бренда. В настоящее время производство в индустрии туризма и трансформаџия национального производства в бренд очень важны в развитии туризма. В челях развития туризма в Ферганской долине планируется использовать обновление продукции Кокандской бумаги, а также развивать туристические маршруты вдоль территорий, на которых была изготовлена бумага.
\end{abstract}

Ключевые слова: туризм, национальная продукция, бренд, Кокандская бумага, Самаркандская бумага, туристический марирут, мировой опыт.

The Republic of Uzbekistan has a rich historical and cultural heritage. This gives an opportunity to develop the tourism industry, which does not fully use the tourist potential, and also turn Uzbekistan into one of the main tourism centers of the world. Tourism is one of the factors accelerating the processes of economic development, and it plays an important role in solving the economic and social problems. The place of tourism is great in creating additional work places, as well as improving the national welfare. It is also very important that Uzbekistan is a quiet and peaceful country, also has a beautiful and unique nature, hospitality of local people. Therefore, day by day, the flow of tourists from countries of the world is gradually increasing. To date, Uzbekistan is considered one of the countries of the world which is widely developing the tourism industry. The production of exotic national brand goods also plays an important role in the development of tourism in the country. It should be noted that once in Samarkand by local craftsmen was produced the highest quality paper in the world of those times. At the same time, paper was produced in the city of Kokand. Kokand paper was famous for its best quality in Central Asia in the Middle Ages. It is important to make extensive use of the foreign countries experience to develop this sphere. It is known that many countries successfully practice the merit of traditional paper production for the development of the tourism industry. Human mankind is always grateful to the Chinese technogenic culture, for inventing paper. Today, many states use traditional paper production for the manufacturing of tourism products and to develope of tourism. For example in Turfan city [6, p. 26]. Dongguan city [6, p. 28] of China there were continuing production of traditional paper manufacturing as a national brand. Tourists, visiting Donghuang, can get full information about paper production process and progress of the book printing art in China. The city of Kairouan [6, p. 30], of Tunisia, in the city of Fez [6, p. 35] of Morocco, also in the state of Rajasthan of India, people keep secrets of paper production almost for 600 years. Here, the paper manufacturing process is carried out in accordance with the methods of "hand made" and "environmentally friendly" [6, p. 39]. The city of Eshizen [6, p. 45.] of Japan, the city of Fabriano [6, p. 47], of Italy, the city of Mýrnák and Vidolen-les-Annoné [6, p. 51] were known for their workshops on traditional paper production. Many foreign scientists studied the history of paper production, such as Pierre-Marc de Beasie, Marie Elec Reynaud, Dominique Buissot, H. Brian, B. Gerard, Lenaik Le Dungu, Vyatkin V.A., Wamburn A., Likhachev N.P., Fedchenko A.P., Zotov P.D., Murodov A., Kaziev A.Yu., Kukushkin K.V., Malkin I.T., Fotiev S.A., Semenov A.A., Mouqminov R.G., Sukhareva O.A., Khalidov A. B. Razvodovsky V.K., Potanin V., Poshino P.N. 
Unfortunately, in the XVIII-XIX centuries due to the political crisis, the Samarkand school of paper manufacturing fell into decay. Masters of paper production moved to a more politically stable city - Kokand. The city of Kokand constantly was a center of handicraft and trade. The sphere of paper making also developed highly as other areas of handicraft [10, p. 239]. Indeed, the city of Kokand was famous in the East for its highquality and soft paper [1, P. 112.]. In Kokand also other crafts developed highly, related to the book printing industry, such as: covercraft, book illustration, art, calligraphy. As A.A. Semenov noted, "The Kokand paper was so well known in its time that even aristocrats of the capital of Russia - St. Petersburg, became interested in this paper and ordered it for themselves [5, p. 5]. A.P. Fedchenko in his memoirs wrote: "The paper making shops in the Kokand Khanate are the only factory in this direction in Central Asia. One of them was in Chorsu, and the second was in Mui Muborak. The methods of paper manufacturing in these factories were amazing. "According to A.P. Fedchenko, the method of Kokand paper making was very similar to the Chinese method [7]. N. Khabibullayev expressed his opinion on this issue, this way: "It's amazing, that the masters of Central Asia have preserved and developed Chinese masters' paper manufacturing methods and skills. Despite the fact that they mostly used manual labor and the technique was obsolete, they were able to raise the art of high-quality paper making. This is due to the custom of preserving the traditions of our ancestors among our people" $[8, \mathrm{p}$. 23]. The largest craftsmanship in the paper industry was in Mui Muborak, near the Mui Muborak River. In 18631873 in connection with the construction of the palace of the Kokand Khan, all the shops moved to the villages of Kalach and Tul, which belonged to the Sokh district. These shops functioned until the 1930 [2, p. 93,94]. As it is written above, Kokand paper was known for its high quality. This paper was exported even to Koshgar, northern Afghanistan and Egypt. These types of paper were used to print money in the Emirate of Bukhara [3, p. 8]. Kokand paper could compete with Chinese paper in its quality, elasticity and softness. Because there was no paper transparent and gentle except for Kokand paper. Such a paper is transparent to such an extent that the inscription written on such paper could be read from both sides. Also Kokand paper did not get wet with water, it was strong, it did not break when pulled. There were almost 10 kinds of Kokand paper. Including species "Abribahor", "abryshem", "haftrang" were very famous. The paper "Abriabahor" was made of Egyptian paper [8, p. 35]. Despite the fact that, Kokand paper was of excellent quality, because of its high cost and poor life, customers and those who wanted paper was not enough. Often it was ordered by rich people. Such a paper was used for the khan's office correspondence, decrees, documents and papers [8, p. 61]. Young artists - miniaturist Shomakhmud Mukhammadzhonov and ornamental artist Maruf Salimov restored the art of the Kokand "abro" [9, p. 25]. The last master of the art of "abro" was Mirza Kairullo Candy in Kokand. After his death in 1942, there was no master in the "abro" paper manufacturing in Central Asia. But this art was preserved in Turkey and in other countries of the East. The "abru" art came to Europe as "abra paper" or "Turkish paper", and some researchers consider the "abru" art as a paper, but this art appeared in the East with the development of calligraphic art [11]. Using the foreign experience mentioned above, as well as local experience, it is possible to expand production of paper in the village of Ovchi, which is popularly known as "Mui Muborak" near the city of Kokand. The restoration of the Kokand paper production can play the role of a national brand of the city of Kokand and turn into a tourist phenomenon. According to the American scientist David A. Acker about the brand's productsit is necessary to further develop existing brands, and diversify the types of products, in order not to reduce the status and reputation of the brand, to preserve their reputation and image for consumers and competitors [4, p. 2]. Any developing state tries to enter the world market with its goods or services, find its place, tries to enter the list of advanced states in the world market. It is necessary to develop those areas of the economy and art, the production of goods and services that can quickly bring publicity to the state, increase its popularity [4, p. 3]. The national brand is the scientific and educational potential, cultural traditions, natural recreational resources. Today, Uzbekistan is recognized as a state with a great potential in the production of goods and services with the brand "Made in Uzbekistan".

If we want to restore the Kokand paper as a national brand and enter with it into the tourism industry, it is necessary to perform the following activities:

- to create a program for the comprehensive development of the Kokand paper and the directions like the art of calligraphy, the art of "abro" and others;

- to prepare qualified masters for the production of Kokand paper;

- to study the feasibility of producing Kokand paper in historical localities;

- to study the importance of restoring the Kokand paper manufacturing to create a tourist image of the local communities;

- to study the demand for the tourism market products;

- to develop an advertising campaign for notifying the public and turn the Kokand paper as to a national brand;

- to produce souvenirs made from Kokand paper;

- to reduce the trade and commodity market of the Kokand paper as a national brand.

Thanks to the restoration of the Kokand paper, the "Kokand art of miniature" and "Kokand art of calligraphy" will again develop. These art trends also have an important role in the development of the tourism industry, and 
making souvenirs and other tourism products, increase their competitiveness, and we can use the experience of tourist powers, for example, India, to develop handicrafts.

These proposals and conclusions have one goal - try to make Uzbekistan also become a state with a developed tourism industry. Improve the image of the country. Also it is necessary to create a tourist tourist route through the villages where Kokand paper is produced. Including, to develop a route along the villages "Kokand - Mui Muborak - Uchkuppik - Sukh - Kalachach - Tul" is very expedient. This task gives a chance to develop the tourist infrastructure in these settlements, and the development of the economy in the country as a whole. And, of course, it increases the welfare of these villages people.

\section{References / Сиисок литературы}

1. Begmatov H. "Kukon kogozini ishlab chikarish tarihiga doir", "Ta'lim va tehnologiya". Tashkent, 2012. P. 112.

2. Begmatov H. "Kakandskaya bumaga proizvodstva", "Ta'lim va tehnologiya". Tashkent, 2013. P. 93, 94.

3. Isabaeva G. "Kukon madaniy hayoti" monografiya. Tashkent published by "IKTISDIYOT". P.8.

4. Kuvvatov A. "Turizm faoliyatini baholashda yordamchi hisoblarning ahamiyati"; "Iktisidiyot va innovacion tehnologiyalar" e-journal, 2011. № 2. P. 2-3.

5. Murodov A. "Urta Osiyo hattotlik san'ati tarihidan". Tashkent, 1971. 196 p. [E'lektronniy resurs]. Rezhim dostupa: uzhistory.uz/content/download/307/2016/file/Xalnazarova_L.pdf/ (data obrashcheniya: 15.11.2017).

6. Osenna E. "Kogoz yuli - globallashuvga kiskacha yul" 2015. Samarkand. Published by "Zarafshan". P. 26, $28,30,35,39,45,47,51$

7. Sobirov N. "Kukon kogozi"; gazeta "Halk suzi”. Uzbekistan, 199111 maya.

8. Habibullayev N. "Urta Osiyoda kogoz ishlab chikarish tarahi” Tashkent 1992.P.23,35,61. [E'lektronniy resurs].

Rezhim

dostupa: http://iisdev1.library.illinois.edu/Uzbek/Content/PDFs/1992.wd.macro_ezhedgodnik.knigi.pdf/

(data obrashcheniya: 15.11.2017).

9. E'sonov Z., Begmatov H. "Kukon kogozini ishlab chikarish tarihidan". Kokand, 2009. P. 25.

10. Begmatov $H$. The formation and development of paper work trade in Fegana valley, "Ta'lim va tehnologiya". Tashkent, 2015. P. 239.

11. [E'lektronniy resurs]. Rezhim dostupa: www.dokusu.com/ebru-sanati-nedir/ (data obrashcheniya: 15.11.2017). 